\title{
Meribeth Bunch
}

\section{Dynamics of}

the Singing Voice

Third edition 
Meribeth A. Bunch, Ph.D.

Consultant in Voice, London, England

\section{With illustrations by Audrey Besterman}

Consultant for Anatomical Portions: Ruth E. M. Bowden

This work is subject to copyright.

All rights are reserved, whether the whole or part of the material is concerned, specifically those of translation, reprinting, re-use of illustrations, broadcasting, reproduction by photocopying machine or similar means, and storage in data banks.

(c) 1982, 1993, and 1995 Springer-Verlag Wien

Originally published by Springer-Verlag/Wien, New York in 1995

Softcover reprint of the hardcover 3rd edition 1995

Printed on acid-free and chlorine-free bleached paper

\section{With 68 Figures}

Library of Congress Cataloging-in-Publication Data

Bunch, Meribeth, 1938-

Dynamics of the singing voice / Meribeth Bunch. -3 rd ed.

p. $\mathrm{cm}$.

Includes bibliographical references and indexes.

ISBN 978-3-211-82623-2 (Wien : acid-free paper).

1. Singing-Physiological aspects. 2. Voice-Care and hygiene.

3. Voice disorders. I. Title.

QP306.B86 1995

$612.7^{\prime} 8$ - dc20 


\section{Preface}

Every discipline tends to develop its own particular language and ways of communicating. This is true also about the various disciplines that talk about and describe the human voice - particularly as it relates to singing. The aim of this book is to bridge any gaps in communication, foster better understanding of the singing voice and encourage collaboration between those involved in performance, teaching, therapy and medicine. Because there is increasing interest in research in all these disciplines, creating a "common ground" for communication about the singing voice is essential for mutual understanding and for effective prevention and treatment of disorders in singers. One object for the artistic and scientific professions is to understand each other better by finding a vocabulary and terminology which they can share and use effectively.

Difficulty in communication often arises when a singer or teacher of singing attempts to describe something sensory in nature by use of imagery and sign-language to non-singers, including the health and medical professions; and, in the same way, the use of obscure and sometimes frightening terminology by those in the medical sciences when offering explanations to singers. Teaching and simple language was and is needed from both sides.

A number of advances are helping to create rapid change in bridging gaps in communication and in adding new information:

1. The formation of Associations for Performing Arts Medicine on a national and international scale are bringing new awareness to those who work with singers and other artists.

2. Laboratories for research on the voice have been built in numbers of cities and countries throughout the world. Here teachers of singing and graduate students are working along side doctors and speech therapists to find better ways of understanding the voice.

3. A number of new journals reporting research on the voice are being published. These, along with the computerised data, have made bibliographical searches much easier.

4. Computerised data banks on research relating to voice are being established thereby enabling many to have access to both old and new knowledge.

5. Developments in technology have led to more effective and less invasive methods of observing the voice and to more accurate analysis of data. 
6. Teachers of singing are sharing knowledge around the world through international meetings and symposia.

7. Exploration of freeing the body and voice through various means such as dance, movement, Alexander technique and alternative therapies is becoming standard practice.

8. Recent research on emotions is likely to arouse much interest. In fact, there is a proliferation of literature looking at physical, mental, emotional and even metaphysical aspects of sound and singing.

In short, the horizons of research and gathering of information are expanding rapidly.

This edition of Dynamics of the Singing Voice retains much of its original information on vocal research with the exception of small alterations throughout. Other changes and additions include recent work on emotions and life energy of music and singing, revision, topical arrangement and updating of the bibliography to make it more usable and additional information on a few of the many adjunct therapies available to singers.

This book is a compilation of the thinking, ideas and creativity of many. It would be impossible to name all the students, teachers and colleagues (medical and musical) who have directly or indirectly contributed to the ideas contained in these pages. However, I must express my gratitude for the wise teaching and hours of enlightening discussion with the late William Vennard, a singer and teacher of distinction, the patience of those who have taught me singing including Joan Jacobowsky, Audrey Langford and Angela Caine, a close musical friend, Shibley Boyes and Professor R.V. Gregg who first taught me anatomy.

Without the skilled correction, discussion and editorial contribution of Professor R. E. M. Bowden this book might never have been written. Not only did she give of her profound knowledge of anatomy, which she taught at The Royal Free Hospital School of Medicine and The Royal College of Surgeons for many, many years, but also her excellent literary skills. For all that I am deeply grateful. My thanks also to the photographic departments of the Royal College of Surgeons, the Royal Free Hospital School of Medicine and the Institute of Neurology; and to these institutions for giving me bench space and help with my original work; to Rita Farrell for her guidance and work on the early stages of the original manuscript; to Gloria Prosper who contributed to the early stages of the Bibliography; more recently to the Central School of Speech and Drama and The National College of Speech Sciences; and to the National Institutes of Health for the research grant which made it possible for me to find the time to further my own research and to write the first edition of this book, and finally to Jane Vukovic for her support on subsequent editions. 


\section{Contents}

1 Introduction $\ldots \ldots \ldots \ldots \ldots \ldots \ldots \ldots \ldots \ldots \ldots \ldots, 1$

Terminology used to describe singing $\ldots \ldots \ldots \ldots \ldots \ldots \ldots, 2$

Understanding the processes of producing sound $\ldots \ldots \ldots \ldots .2$

Relating functional processes to the teaching of singing $\ldots \ldots$. 4

Relating function to artistry $\ldots \ldots \ldots \ldots \ldots \ldots \ldots \ldots, 4$

Relating personal growth to singing and artistry $\ldots \ldots \ldots \ldots \ldots$. 5

How to use this book $\ldots \ldots \ldots \ldots \ldots \ldots \ldots \ldots \ldots$

2 Psychological aspects of singing $\ldots \ldots \ldots \ldots \ldots \ldots \ldots \ldots, 7$

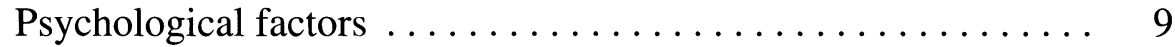

Physiological factors $\ldots \ldots \ldots \ldots \ldots \ldots \ldots \ldots \ldots \ldots \ldots, 11$

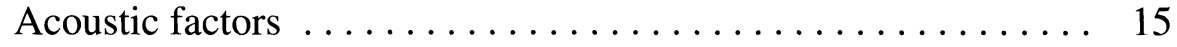

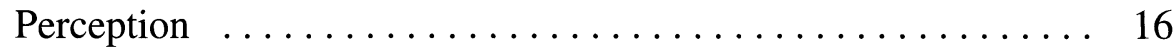

Psychological aspects of teaching and studying singing $\ldots . .18$

Sensory-motor awareness $\ldots \ldots \ldots \ldots \ldots \ldots \ldots \ldots . \ldots \ldots$

The language and communication involved in teaching and learning .............................. 19

The contribution of the teacher $\ldots \ldots \ldots \ldots \ldots \ldots \ldots \ldots, 20$

Contribution of the student $\ldots \ldots \ldots \ldots \ldots \ldots \ldots \ldots \ldots 21$

3 Posture and breathing in singing $\ldots \ldots \ldots \ldots \ldots \ldots \ldots, 23$

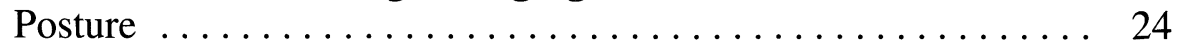

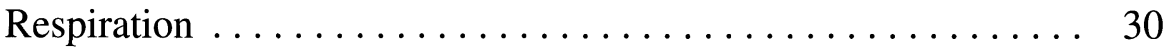

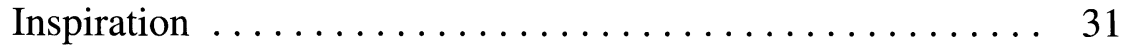

a) The diaphragm $\ldots \ldots \ldots \ldots \ldots \ldots \ldots \ldots \ldots \ldots \ldots$

b) The intercostal muscles ................ 37

c) Other muscles of inspiration $\ldots \ldots \ldots \ldots \ldots \ldots \ldots, 45$

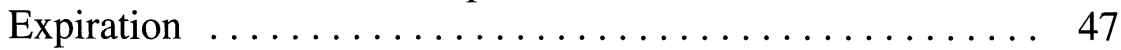

a) The abdominal muscles .................. 47

b) Other muscles of expiration $\ldots \ldots \ldots \ldots \ldots \ldots, 50$

Subglottic pressure ......................... 51

Summary: breathing for singing $\ldots \ldots \ldots \ldots \ldots \ldots \ldots, 53$ 


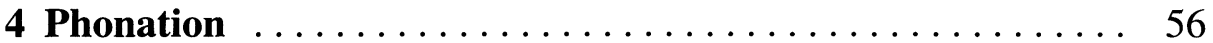

The anatomy of the vibratory mechanism $\ldots \ldots \ldots \ldots \ldots \ldots 57$

The function of the vocal folds in singing ............. 69

The attack ....................... 70

Neurological factors of phonation $\ldots \ldots \ldots \ldots \ldots \ldots . \ldots \ldots$

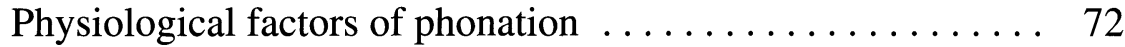

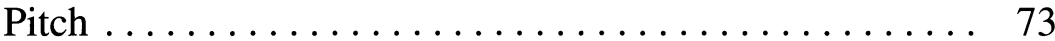

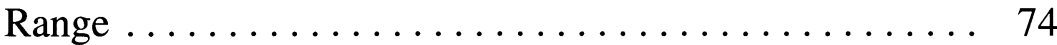

Vibrato ......................... 75

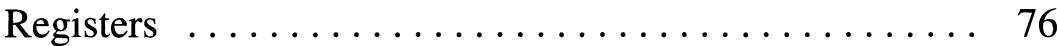

Subglottic pressure and vocal intensity $\ldots \ldots \ldots \ldots \ldots \ldots 80$

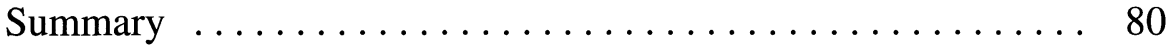

5 Resonation and vocal quality $\ldots \ldots \ldots \ldots \ldots \ldots \ldots \ldots 2$

The anatomy and physiology of the pharynx $\ldots \ldots \ldots \ldots . . \ldots 5$

The constrictors ...................... 89

The longitudinal muscles $\ldots \ldots \ldots \ldots \ldots \ldots \ldots \ldots \ldots . \ldots 9$

The soft palate $\ldots \ldots \ldots \ldots \ldots \ldots \ldots \ldots \ldots \ldots \ldots$

A summary of the acoustics of the vocal tract $\ldots \ldots \ldots \ldots \ldots . . \ldots 3$

Vowel formation ...................... 99

Vocal quality ......................... 102

Factors which affect vocal quality $\ldots \ldots \ldots \ldots \ldots \ldots \ldots 102$

Focus and intensity . .................... 105

Some misconceptions regarding resonance $\ldots \ldots \ldots \ldots 107$

Conclusion .................................. 109

6 Articulation ............................ 111

Vowels and consonants: a summary of their articulation ..... 112

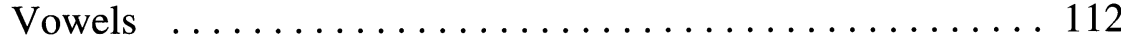

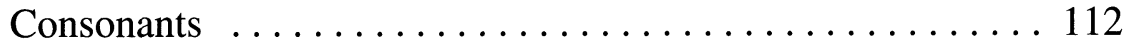

The mechanism of articulation $\ldots \ldots \ldots \ldots \ldots \ldots \ldots \ldots \ldots$

Anatomical aspects of articulation $\ldots \ldots \ldots \ldots \ldots \ldots \ldots \ldots \ldots$

Fixed structures ........................ 114

Movable structures .................... 114

a) The mandible or lower jaw $\ldots \ldots \ldots \ldots \ldots \ldots \ldots$

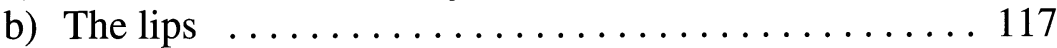

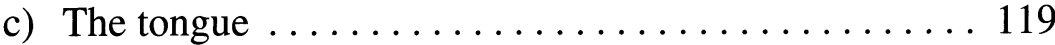

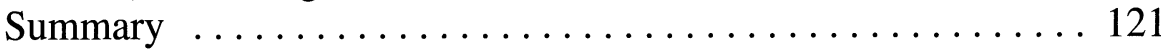

7 Vocal problems: their prevention and care $\ldots \ldots \ldots \ldots \ldots 123$

General health and nutrition $\ldots \ldots \ldots \ldots \ldots \ldots \ldots \ldots \ldots$

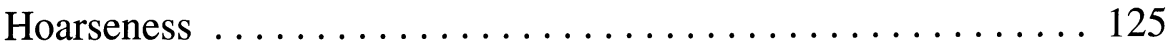

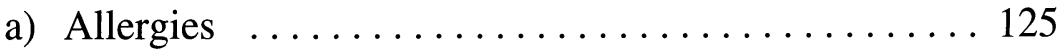




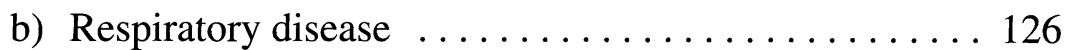

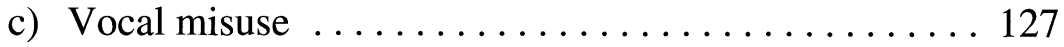

d) Hoarseness of psychogenic origin $\ldots \ldots \ldots \ldots \ldots \ldots 130$

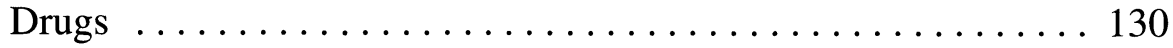

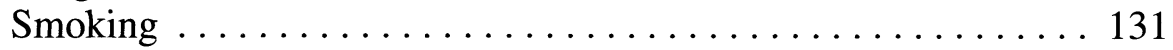

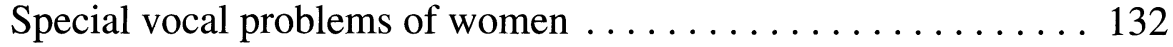

Surgical procedures pertinent to singers $\ldots \ldots \ldots \ldots \ldots \ldots 132$

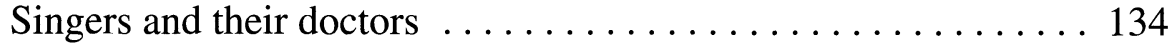

Other professionals in health available to singers $\ldots \ldots \ldots \ldots 135$

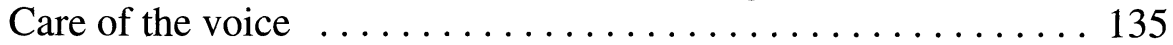

8 Co-ordination, spontaneity and artistry $\ldots \ldots \ldots \ldots \ldots 138$

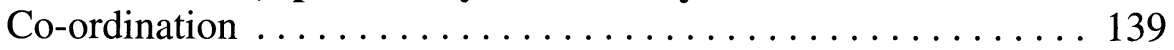

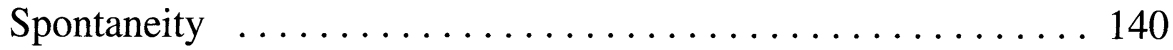

Artistry .............................. 143

a) Love of singing $\ldots \ldots \ldots \ldots \ldots \ldots \ldots \ldots \ldots \ldots \ldots \ldots \ldots$

b) Dedication to the work of singing . . . . . . . . . 144

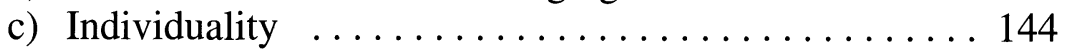

d) Emotional involvement ................ 145

e) Personality and magnetism ............. 145

f) Performance that transcends the ordinary ....... 146

On becoming a dynamic singer $\ldots \ldots \ldots \ldots \ldots \ldots \ldots \ldots \ldots$

9 Singing from the heart $\ldots \ldots \ldots \ldots \ldots \ldots \ldots \ldots \ldots \ldots$

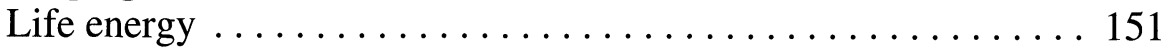

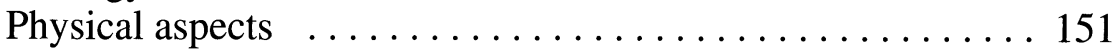

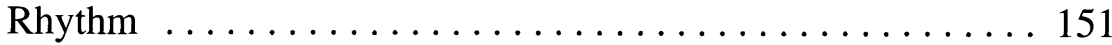

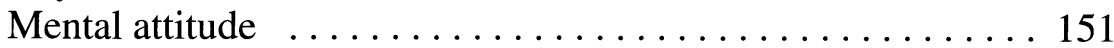

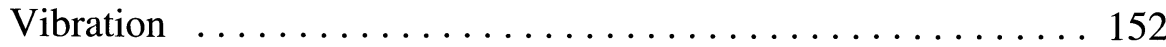

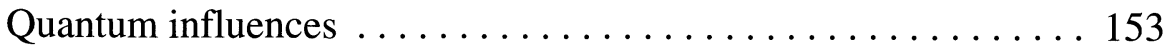

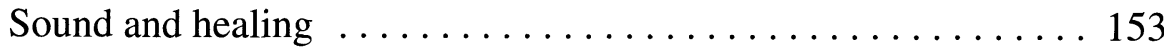

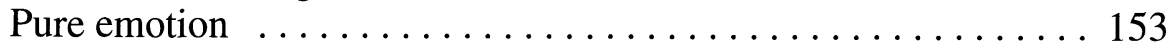

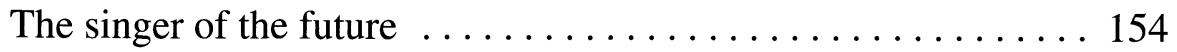

References ........................... 156

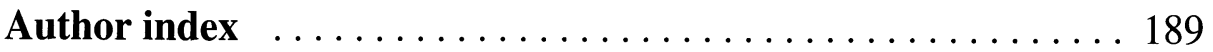

Subject index $\ldots \ldots \ldots \ldots \ldots \ldots \ldots \ldots \ldots \ldots \ldots \ldots \ldots \ldots$ 